\title{
TEACHER-LIBRARIANS IN LEARNING ORGANIZATIONS
}

\author{
Jean Brown \\ Associate Professor \\ Faculty of Education \\ Memorial University of Newfoundland \\ St. John's, Newfoundland \\ Canada, A1A 3X8 \\ E-mail: jbrown@morgan.ucs.mun.ca \\ Bruce Sheppard \\ Associate Professor \\ Faculty of Education \\ Memorial University of Newfoundland \\ St. John's, Newfoundland \\ Canada, A1A 3X8 \\ E-mail: bsheppar@calvin.stemnet.nf.ca
}

\begin{abstract}
Teacher-librarians must function both as members of teams engaged in organizational learning and as leaders of leaders. The teacher-librarian, therefore, must be a mirror image of other teacher leaders, while also bringing added value as a leader in teacher-librarianship. To meet the needs of schools if they are to be learning organizations, teacher-librarians will need a unique blend: a knowledge base; technical skills; interpersonal and team skills; and a particular system of values and beliefs. Credibility as a teacher with colleagues and the principal is crucial for success.
\end{abstract}

\section{TEACHER-LIBRARIANS IN LEARNING ORGANIZATIONS}

Within the last decade, reform efforts have dominated the educational landscape throughout the world (Cousins, 1996; Fullan, 1993; Sheppard \& Brown, 1996). In spite of such emphasis on reform, research suggests that these efforts may not result in the improvements in student achievement that are anticipated by reformers (Bremen \& MacLauglin, 1976; Deal, 1990; Cranston, 1994; Fullan, 1993, 1995; Murphy \& Hallinger, 1993; Sarason, 1990; Sergiovanni, 1995; Sheppard \& Brown, 1995). Murphy and Hallinger's (1993) research indicates that "at neither the theoretical nor the conceptual levels was there much evidence to link...restructuring efforts with changes in classrooms, relationships between teachers and students, and/or student outcomes." (p. 254) For example, in spite of the emphasis throughout the world on school councils, Fullan (1995) concludes that the empirical evidence in the literature up to this point is that the majority of councils are not successful. Similarly, even though theories of leadership are moving away from technological, rational planning models, toward cultural, collaborative approaches in which teachers are viewed as partners (Blase, 1993; 1987; Evans, 1993; Griffiths, 1988; Laroque \& Coleman, 1991; March, 1988; Pellicer, Anderson, Keefe, Kelley, \& McCleary, 1990; Weber, 1989), Clark \& Clark's (1996) research reveals that "In spite of the many benefits of working in collaborative environments, there is considerable evidence that many teachers still work in isolation." (p. 2)

In light of the uncertainty of reform efforts, "the generative concept of the learning organization" (Fullan, 1993, p. 6) provides the basis of a promising theoretical framework for the development of better schools. Redding and Catalanello (1992) contend that "amid sometimes unpredictable, always uncertain, highly turbulent business conditions, an organization's capacity to learn as it goes may be the only true source of competitive advantage." (p. 52) Similarly, Handy (1995) argues that: 
In an uncertain world, where all we know for sure is that nothing is sure, we are going to need organizations that are continually renewing themselves, reinventing themselves, reinvigorating themselves. These are the learning organizations, the ones with the learning habit. Without the habit of learning, they will not dream the dream, let alone have any hope of managing it. (p. 45)

While the concept of the learning organization has developed outside of the school setting (Senge, 1990), research within education (Fullan, 1993; Leithwood, Dart, Jantzi \& Steinbach, 1993; Louis, 1994) supports its meaningfulness in the school context. Fullan (1995) contends that if we are to succeed in bringing about meaningful improvement "schools must become learning organizations." (p. 234) Louis, Kruse and Raywid (1996) contend that:

The current reform movement focuses on structural and curricular changes as the main ingredients of effective schools, but pays less attention to altering the day-to-day work of teachers. When schools are seen as learning organizations and professional communities, however, attention is focused on teachers' work as the key instrument of reform. By emphasizing needed changes in the culture of schools and the daily practice of professionals, the reform movement can concentrate on the heart of the school-the teaching and learning process. (p. 7)

The concept of the learning organization is grounded in the five" learning disciplines-lifelong programs of study and practice" expounded by Senge (1990):

Personal mastery-learning to expand our personal capacity to create the results we most desire, and creating an organizational environment which encourages all its members to develop themselves toward the goals and purposes they choose.

Mental models-reflecting upon, continually clarifying, and improving our internal pictures of the world, and seeing how they shape our actions and decisions.

Shared vision-building a sense of commitment in a group, by developing shared images of the future we seek to create, and the principles and guiding practices by which we hope to get there.

Team learning - transforming conversational and collective thinking skills, so that groups of people can reliably develop intelligence and ability greater than the sum of individual members' talents.

Systems thinking - a way of thinking about, and a language for describing and understanding, the forces and interrelationships that shape the behavior of systems. This discipline helps us to see how to change systems more effectively, and to act more in tune with the larger processes of the natural and economic world. (Senge, Roberts, Ross, Smith, \& Kleiner, 1994, p. 6)

While some practitioners and researchers found these five disciplines somewhat abstract (Senge et al., 1994), they and others have attempted to identify other characteristics, consistent with these disciplines, that are somewhat more concrete. Redding and Catalanello (1992) envisage four defining characteristics of the learning organization: constant readiness; continuous planning; improvised implementation; and action learning. Similarly, Marsick and Watkins (1996) identify seven action imperatives for building learning organizations: creation of continuous learning opportunities; promotion of dialogue and inquiry; encouragement of collaboration and team learning; establishment of systems to capture and share learning; empowerment of people toward collective vision; connection of the organization to its environment, and leaders who model and support learning at the individual, team, and organizational level.

Organizational changes needed in the development of schools and districts as learning organizations require a major transformation in models of leadership and teachers' roles (Fullan, 1995; Sheppard \& Brown, 1996). However, it is not surprising that leadership patterns and professional practices in schools and school districts are deeply engrained features of the educational culture that cannot be changed by simply declaring new values. "Deep beliefs and assumptions change as experience changes, and when this happens culture changes." (Senge et al., 1994, pp. 20- 
21) If we are to develop learning organization, the professional leadership of teachers must be developed. The required professional development cannot be delivered through traditional models of professional development that are dependent upon the one day workshop delivered by an "expert." Ryan (1995) contends that learners' in this expert model are generally assumed to be "ignorant, passive, empty vessels who can be effectively filled up by the expert expounding knowledge." (p. 279) As a consequence of such inadequate professional development, "many teachers and others say they do not want to 'be developed'. In other words, they are not looking for other people to be responsible for their learning...[ In a learning organization], "ultimately everyone, supported by colleagues, is responsible for their own learning." (Stoll \& Fink, 1996, p. 164) Marsick \& Watkins (1996) describe one model of professional development whereby "adult educators in the learning organization assist in the design of self-directed learning and bring learning to people's desks through the decentralized use of computer-based learning systems." (p. 19)

In like manner, Sparks (1996) contends that while professional development is essential if teachers and administrators are to avail of the findings of research on teaching, learning, and leadership, it must be considerably different from past practice. It must not only affect, "the knowledge, attitudes, and practices of individual teachers, administrators, and other school employees, but also the culture and structures of the organizations in which those individuals work," in other words, a major paradigm shift:

This new form of professional development represents a "paradigm shift." Some of the most important of these shifts represent: an increased focus on both organizational and individual development; staff development efforts driven by clear and coherent strategic plans; a greater focus on student needs and learning outcomes; an inquiry approach to the study of the teaching/learning process by teachers; an inclusion of both generic and content specific pedagogical skills; and greater recognition that staff development is an essential and indispensable part of the reform process. (p. 260)

Similarly, Cousins (1996) states that the redefined leadership role for teachers goes beyond their involvement in school wide activities, that it requires a focus on the classroom and "students' rights to a learner-centred pedagogy." (p. 31) He further observes that if such leadership is to exist, teachers must have opportunities for professional development that needs to take place within the school, rather than in locations outside it.

A major component of professional development in learning organizations occurs as teachers engage in action research which requires them to gather and use new information to challenge the status quo. Sparks (1996) states that "to become learning organizations schools must engage in organizational development activities...based on continual data collection, analysis, and feedback, focusing on the development of groups and individuals to improve group functioning." (p. 262) If schools are to engage in such activities, teams may find some of the information they need in the school, but they will also need to look beyond their school for information (Vail, 1996). For that purpose, Cousins (1996) suggests that if schools and school districts are to be learning organizations, there should exist a strong research department that would not only collect and analyze data on the school, but would also compile literature reviews, and routinely scan news media. While the primary base for such a department would exist at the district level, there would also be a team that would carry out a similar set of tasks at the school level.

It is in the context of current reform efforts and the emerging concept of schools as learning organizations that the Toronto Elementary and Secondary School Teacher-Librarians (1995) ask an essential question related to their future role:

Are teacher-librarians becoming irrelevant stage magicians whose ultimate trick will be to make themselves disappear? or are they pioneering voyagers, reshaping library information centres by engaging future technologies with critical expertise and imaginative joy? (pp. 2-3)

Galbraith and Lawler (1993) provide an image of role structures in decentralized and lateral work environments such as the learning organization. That image is quite useful as a guide to reflection regarding those questions posed by the Toronto teacher-librarians. They note that "more companies are creating matching, mirror-image structures across as many functions as possible." (p. 48) These mirror-image structures require that there exists a specialist who is a mirror-image of another in each 
division of the organization or on each team. For example, in each division there would be those with matching skills in specialized areas which would enable each team to have the expertise they need to make site-based decisions. However, we recognize, as does Galbraith and Lawler, that this sometimes presents a problem since there may not be enough work in the area of the specialized function to support a full-time specialist. To deal with that efficiency problem, these organizations have organized into groups which include members who are mirror-images of each other or generalists but in addition, members have their areas of specialization. This allows employees to work laterally with their mirror-image counterparts in many aspects of their work; however, the remainder of their work remains specialized. Galbraith and Lawler argue that in the future greater numbers of organizations will be structured in this way, so that most employees will be mirror-images of each other, but able to add expertise as part of their work when it is required-in other words, act as mirror-images plus when needed.

Galbraith and Lawler contend that increasingly much of the expertise required by the generalists will be accessible through improved information technology:

Already, electronic mail (E-mail), conferencing on personal computers (PCS) and fax machines, and video conferencing can connect every person in a company with every other person. Fiberoptic networks and next-generation PCS will permit video calls from anyone to everyone. The technology removes some barriers by providing connection between people. Whether connection leads to communication and then to coordination depends on the organizational design. (Galbraith \& Lawler, 1993, p. 49)

If teacher-librarians wish to be pioneering voyagers or even to be effective team players in schools that are learning organizations, they need to be mirror-images of other teacher leaders, while also bringing added value as leaders in teacher-librarianship. To meet this demand, teacher-librarians will need a unique blend of characteristics in the following four categories: knowledge base, technical skills; personal, interpersonal and team skills; and a particular system of values and beliefs. Some characteristics within each category will be shared by teachers and teacher-librarians, which is to say that they will be mirror-images of each other. However, teacher-librarians will also be expected to possess added qualities-the plus of the "mirror-images plus."

This mirror-image plus concept is consistent with the position articulated by the International Association of School Librarianship (1995) that "school librarians be qualified teachers who have, in addition, completed professional studies in librarianship." (p. 2) It is also supported by this statement from the Association for Teacher-Librarianship in Canada (1996) that "the teacher-librarian needs to be a highly skilled teacher as well as a librarian, able to function on the school team as a professional with competencies from teacher education and classroom experience as well as from library and information studies" (p. 8).

The American Association of School Librarians recognizes that the educational landscape is changing and that "research on the restructuring of schools calls for the teacher's role to change from a textbook lecturer to that of coach. Students become active learners who create their own knowledge after interacting with information from a variety of resources...often referred to as resource-based learning." (American Association of School Librarians [AASL], 1996a, p. 1) Such an approach requires that members of the educational community "become partners in a shared goal, providing successful learning experiences for all students." (AASL, 1996a, p. 2) In this role the teacher-librarian works with the teacher to plan, design, deliver, and evaluate instruction, serves as teacher and consultant; provides leadership, expertise, and advocacy in the use of technology and resources, encourages students to accept responsibility for their own learning, and manages personnel, resources, facilities, and services that assist students to learn how to learn. The teacher-librarian is viewed as the essential link to connecting students, teachers, and others with the information resources that they need and therefore, "plays a unique and pivotal role in the learning community." (AASL, 1996b, p. 2) The Association describes this role as follows:

School library media specialists [teacher-librarians] are an integral part of the total educational team which prepares students to become responsible citizens in a changing global society. In today's information age, an individuals [sic] success, even existence, depends largely on the ability to access, evaluate and utilize information. Library media 
specialists are leaders in carrying out the school's instructional program through their separate but overlapping roles of information specialist, teacher and instructional consultant. (AASL, 1996c)

In site-based managed schools the AASL contends that teacher-librarians are important members of the decision-making team. They act as partners in instruction, budgeting, program planning, and collection development; they collaborate with teachers in designing, implementing, and evaluating instruction; and they access information sources within and outside the school to guide the staff in decision-making (AASL, 1996d). Vail (1996) argues that in such learning environments, teams need to look beyond their school for information, and that one critical source, still not available to many teachers due to limited technical expertise, is the World Wide Web. An essential role of the teacher-librarian, then, would be to assist others in accessing available sources such as that which is available through the World Wide Web.

This position is consistent with that which is taken by The Toronto Board of Education Teacher-librarians (1996) who view themselves as providing educational leadership in a manner that will "encourage and support all students in becoming life-long learners and agents of change, who are self motivated, thoughtful, and literate." (p. 2) This educational leadership will take the form of collaboration with teachers; sharing professional expertise in curriculum design, learning and teaching strategies, and resource materials; serving on various committees; seeking opportunities for professional growth; extending professional growth of administrators, teachers, and support staff, especially in technology; and facilitating the sharing of information with other agencies.

The demands placed on schools today, urban and rural, are intensified by globalization, declining resources, greater calls for accountability, and the impact of information technology. The roles of teachers and administrators are in transition, as all must be leaders within learning organizations and effective users of information technology. As a consequence of these role changes, the role of the teacher-librarian, as one of the school's leaders in accessing all forms of information required in teaching and learning, is also in transition. Like other teachers and educational leaders, teacher-librarians need be leaders in this new environment and they must develop a specialized expertise to facilitate organizational learning within their schools by placing a priority on staff development and school-wide improvement initiatives. The research reported here will show how some principals, teachers, and teacher-librarians are facing this challenge and help us better understand how to move in this direction.

\section{Methodology}

For the past three years we have been building a research program investigating leadership for change in schools and districts. Working within the conceptual framework of Senge's learning organization, we have been engaged in four different but related studies. Study One, now in its second year, is a five year study. It began with eight schools, 139 teachers, and 2623 students from one school district in Newfoundland, but it has since been extended to include a total of four districts, 12 schools, 254 teachers, and 4566 students. The 12 schools are located in both rural and urban centers and range in size from 50 to 870 students. Study Two is a case study of two large secondary schools, in two different school districts. Both have been recognized provincially and nationally for outstanding leadership in dealing with change. Both schools have business partners, and both are involved with implementing leading edge technology throughout the curriculum. In both these studies, data were collected using survey instruments, interviews, document analysis (curriculum documents, departmental guidelines and policy documents, school profile information, committee papers and records), observations, and teacher journals. Study Three was conducted in seven schools from Study One and one of the schools in Study Two, and focused on the role of and expectations for the teacher-librarian. The schools were visited and interviews were conducted with the principal and the teacher-librarians in each school during November 1996 and January 1997. As part of the interview, each person was asked to sketch a diagram illustrating how leadership occurred in his or her school. Study Four (in which we are two of four investigators) is research conducted for a special project on school improvement for the Newfoundland Department of Education (1995-97). Qualitative data for this latter study were collected in eight districts and 19 schools, while insights were also gained from survey data obtained from 19 districts, 155 principals, 279 teachers, 223 parents, and 69 students. 
Our data for this paper draws on the holistic view of leadership which we have formed of the entire school in Studies One, Two, and Three. It also is informed by the findings from Study Four. Our analysis followed the steps outlined by Woods (1986). These are: (1) Speculative analysis consisting of "tentative reflection, perhaps revealing major insights, that is done throughout the data collection." (p. 121) (2) Classifying and categorizing, or the creation of major categories within the data. (3) Concept formation, which Woods sees as involving the creation of models, typographies, and theory. We see this as the beginning of theory development regarding teacher-librarianship in schools as learning organizations.

\section{Teacher-librarians as Mirror-images of Teachers and Mirror-images Plus}

Our findings confirm the validity of what Fullan (1993) describes as the "new work of the teacher." In this "new work" teachers must: have a moral purpose-making a difference in the lives of children; have a deepened knowledge of pedagogy; recognize the links between their work and societal development; have purpose and vision and be "highly interactive and collaborative;" be able to work in new structures (teams of teachers, networks of learning); be lifelong learners; and be change agents (see Table 1).

\begin{tabular}{|c|c|}
\hline $\begin{array}{l}\text { Teacher \& Teacher-Librarian } \\
\text { Mirror Images of Each Other }\end{array}$ & Teacher-Librarian: Mirror Image Plus \\
\hline $\begin{array}{l}\text { The new work of the teacher (Fullan, 1993) } \\
\text { - Be committed to a moral purpose --making } \\
\text { a difference in the lives of children } \\
\text { - Deepen their knowledge of pedagogy } \\
\text { - Be cognizant of the links between their } \\
\text { moral purpose and educational policy and } \\
\text { societal development } \\
\text { - Be their own person vis-a-vis purpose and } \\
\text { vision, and at the same time be highly } \\
\text { interactive and collaborative } \\
\text { - Work in new structures - clusters of } \\
\text { students, teams of teachers, common } \\
\text { planning time, links to home and } \\
\text { community, participate in wider networks of } \\
\text { learning. } \\
\text { - Develop the habits and skills of continuous } \\
\text { inquiry and learning } \\
\text { Immerse themselves in the change process } \\
\text { (pp. 80-81) }\end{array}$ & $\begin{array}{l}\text { The new work of the teacher - librarian } \\
\text { - Design training programs as needed, for } \\
\text { groups and individuals, students, teachers \& } \\
\text { others } \\
\text { - Assume a leadership role in school } \\
\text { improvement and staff development } \\
\text { - Be a model of lifelong, independent learning } \\
\text { - Create a learning environment that fosters the } \\
\text { new work of the teacher. }\end{array}$ \\
\hline
\end{tabular}

Table 1: The New Work of the Teacher and the Teacher-Librarian

All staff (administrators, teachers, and teacher-librarians) in the schools in our studies are driven by a moral commitment to help students. Their talk and interests reveal their practice of and interest in pedagogy. They are knowledgeable of the changing economic times, the movement towards a new post-industrial society, and the impact that has on the skills and knowledge students need. Although individuals emerge as strong leaders in their own right, they are also aware of the need for staffs to work together, of the expectation for partnerships with parents, community members, and other professionals. For example, in one district (in Study One), 54\% of the 122 staff members in seven schools identified the whole staff as providing leadership for school improvement. 
Although all those we surveyed and interviewed were highly qualified as teachers, they realized that they needed to be lifelong learners if they were to meet the needs of their students. Teacher-librarians were mirror-images of teachers, in that they exhibited the same characteristics as the teachers. In fact, in our research, it is difficult to distinguish the unique role of the teacherlibrarian. We found that there is an overlap instead of a sharp division between the roles of the teacher and the teacher-librarian. This overlap in roles is readily revealed in Table 2 which provides examples of the qualifications and work assignments of the teacher-librarians studied. For example, all four of the teacher-librarians in Table 2 have extensive experience as teachers, and three are currently assigned classroom teaching responsibilities in addition to their role as teacher-librarian.

This chapter focuses on two major findings of our studies. The first is that, within schools as learning organizations, teacher-librarians must not only possess the expertise required of teacherlibrarians but they must be mirror-images of other teachers if they are to have credibility with them. The discussion of this finding is developed through an analysis of four categories of essential characteristics of the work performed by both teachers and teacher-librarians. These are: knowledge base; technical skills; personal, interpersonal, and team skills; and values and beliefs (Table 3). The second finding is that principals are extremely influential in schoolwide leadership, and teacherlibrarians will only have credibility with them if they are mirror-images of teachers. Without that credibility, they cannot successfully perform their specialist role-that of the mirror-images plus.

\section{Knowledge Base \& Technical Skills (Resource-Based Learning)}

As can be seen from Table 3, two major areas of the work of teachers and teacher-librarians, the knowledge base and technical skills, are grounded in resource-based learning. It is apparent in all schools in our studies that this resource-based learning philosophy is desirable and endorsed in current curriculum documents and guidelines from the provincial Department of Education. The definition of resource-based learning in this context is based on the one from Learning to Learn (Newfoundland Department of Education, 1991): It is a broad philosophical approach to learning which (a) actively involves the student in the centre of all learning activities, (b) is dependent on the articulation of process and content objectives, and (c) requires deliberate teacher planning so that multiple resources and varied teaching strategies are incorporated in all plans. Inherent in this definition is an understanding of child development and learning theory, knowledge of the curriculum and instructional development, and a repertoire of instructional strategies which will allow the teacher to design instruction to meet the needs of learners. Since the focus is on the use of a wide range of resources, all teachers are expected to be familiar with the learning resources appropriate for their grade levels and subject areas. Although resource-based learning does not necessarily require collaborative work, our work on schools as learning organizations reveals that the best work occurs when there is collaborative planning and when teachers engage in planning and teaching together. This is consistent with Fullan's (1993) findings regarding "the new work of the teacher" (Table 1), which requires teachers to be highly interactive and collaborative. 
Teacher-librarians: Examples of Qualifications \& Work Assignment

Sue She is a full time teacher-librarian, in her 20th year of teaching, in an urban school which has a French Immersion stream. She is responsible also for the school's computer lab which adjoins the learning resource centre. She has a Bachelor of Music degree and a B.Ed. (Elementary Education). In addition, she has completed the undergraduate Diploma in School Resource Services. She is bilingual, and provides all services in English and French. She is self-taught in computers, and although she does not see herself as having an aptitude for the technical side of computers, she has learned to install software and be the main troubleshooter for technical problems in the school.

May Fifteen years teaching experience as a high school teacher, twelve of which was as a guidance counselor. Currently she is one of two full time teacher-librarians in an urban secondary school which is on the leading edge of technology. She has a B.Ed, a M. Ed. in School Counseling, and a second M.Ed. in Learning Resources (teacher-librarianship). She and the second teacher-librarian work as a team and are responsible for a compulsory language course which focuses on the research process, taken in the second year of high school (equivalent of grade eleven). This course ensures that all students are taught research skills in a curricular context, including the skills of internet searching for information. Of her role in a dynamic learning environment, she stated, "I couldn't tell you what my role is because it changes every day." She sees herself as a lifelong learner and commented: "I have never felt so ignorant and yet I never felt so accomplished in learning. I have never felt more of a problem solver than since I have taken this [job] on." She concluded: "You can never master it [all the skills you need as a teacher-librarian], you are only going to be evolved to the next level. You are not going to master everything."

Ruth Over 20 years teaching experience. Currently teaching in a rural school. Her teaching assignment for the current year is: $25 \%$ teacher-librarian, 50\% kindergarten, $25 \%$ grade six classroom teacher. She has a B.Ed degree in primary education, a second B.Ed degree in special education, and has completed six of the ten courses for her undergraduate Diploma in School Resource Services. Although she has not completed formal courses in computers in education, she is self-taught with a computer with Internet access at home. She shares responsibility with another teacher for the school's computer facilities. She has taught kindergarten, primary grades, grade four, grade six, special education.

Jim High school science teacher with 16 years experience, currently in his first year as a teacherlibrarian. Jim has completed all course requirements for his M.Ed in School Resource Services except for his final project (which is near completion). Jim has developed considerable expertise in cooperative learning and is a school leader in working collaboratively with others using cooperative learning strategies. He became interested in becoming a teacherlibrarian after working cooperatively with the school's teacher-librarian. Although he has assumed a major role in teaching colleagues to use new technology in the classroom, and is responsible for much of the school's computer resources, he admits that "I am mainly selftaught." He adds, however, that "I want to know it" and that has motivated him to keep ahead of the technology.

Table 2: Teacher-librarians: Examples of Qualifications \& Work Assignment

To be successful, teacher-librarians must be mirror-images of the teachers described above, or, in other words, have credibility as a teacher committed to a resource-based learning philosophy and competent in all aspects of implementing such a program. Currently, all teachers and school administrators (not only the teacher-librarian) are expected to keep up to date and integrate new ideas (including new information technologies) into instruction. On the "plus" side, however, teacherlibrarians need to be knowledgeable 


\begin{tabular}{|c|c|}
\hline $\begin{array}{l}\text { Teacher \& Teacher-Librarian } \\
\text { Mirror Images of Each Other } \\
\text { Knowledge Base(Resource-Based Learning) } \\
\text { - The practice of pedagogy } \\
\text { - Instructional strategies } \\
\text { - Child development } \\
\text { - Learning theory } \\
\text { - Instructional development } \\
\text { - Curriculum knowledge (Theory \& Practice) } \\
\text { - Learning resources--access and use } \\
\text { - Children's literature (Primary/Elementary) } \\
\text { - Educational change process } \\
\text { - Interactive professionalism } \\
\text { - Action research } \\
\text { - Leadership (not management) } \\
\text { - School and society } \\
\text { "Model of good teaching practices" }\end{array}$ & $\begin{array}{l}\text { - National \& Provincial Standards and Guidelines } \\
\text { for Teacher-Librarianship } \\
\text { - Advanced training in instructional development } \\
\text { - The teaching of independent learning skills } \\
\text { - Access to information/ Information networks } \\
\text { - Validation of appropriate learning resources to } \\
\text { meet learning objectives } \\
\text { - Broad range of instructional strategies } \\
\text { - General overview of the school-wide curriculum } \\
\text { and grade levels } \\
\text { - Leadership and change theory } \\
\text { - Staff development \& adult learning principles } \\
\text { "Credibility as a good teacher plus added value as a } \\
\text { teacher-librarian" }\end{array}$ \\
\hline $\begin{array}{l}\text { Technical Skills (Resource-based learning) } \\
\text { - Use of appropriate technology (including } \\
\text { current and traditional technology and } \\
\text { computer technology) } \\
\text { - Up-to-date knowledge of current technologies } \\
\text { - Library user and basic technical skills }\end{array}$ & $\begin{array}{l}\text { - Trainer of technical skills } \\
\text { - Selection and operation of automated library } \\
\text { - systems, technical hardware and software } \\
\text { - Advanced skills in information technology } \\
\text { - Awareness of emerging technologies } \\
\text { - Operation of a learning resources centre }\end{array}$ \\
\hline "Integrating current technology in the curriculum" & "Learn it -- then give it away and move on!" \\
\hline $\begin{array}{l}\text { Personal, Interpersonal and Team Skills } \\
\text { - Likes working with kids } \\
\text { - Leadership skills } \\
\text { - Collaborative team player } \\
\text { - Flexible and open to ideas of others } \\
\text { - Pleasant, friendly personality } \\
\text { - Assertive but not threatening } \\
\text { - Approachable and collegial } \\
\text { - Coach and peer tutor } \\
\text { - Good communicator } \\
\text { - Good presentation skills }\end{array}$ & $\begin{array}{l}\text { - Risk taker } \\
\text { - Group facilitator and trainer } \\
\text { - Instructional leader } \\
\text { - Creator of a collaborative culture } \\
\text { - High tolerance for change \& innovation } \\
\text { - Entrepreneurial/ business skills } \\
\text { - Advanced presentation skills } \\
\text { - Transformational leader /leader as servant } \\
\text { - Delegation and time management skills } \\
\text { - Management skills }\end{array}$ \\
\hline "A spark in the eye for kids and teaching" & "A spark in the eye for independent lifelong learning" \\
\hline $\begin{array}{l}\text { Values and Beliefs } \\
\text { - Equality of educational opportunity } \\
\text { - Moral commitment to improving children's } \\
\text { learning experiences and meeting students' } \\
\text { needs } \\
\text { - Resource-based learning philosophy } \\
\text { - Commitment to collaborative school cultures } \\
\text { - A love of learning and the value of education }\end{array}$ & $\begin{array}{l}\text { - The value of the research process \& systematic } \\
\text { instruction integrated into curriculum for all } \\
\text { - The right of all students to be taught to access, } \\
\text { retrieve and use information technology } \\
\text { - Commitment to independent, lifelong learning } \\
\text { - A commitment to the intellectual \& physical } \\
\text { access to information for all }\end{array}$ \\
\hline "Preparing students for a new age" & "Building a fire truck as opposed to putting out fires" \\
\hline
\end{tabular}

Table 3: Mirror Images \& Mirror Images Plus of the Work of the Teacher \& Teacher-Librarian 
about recent research and developments in teacher-librarianship, have advanced skills in instructional development and information technology, and in accessing information and learning resources. They also need an understanding of staff development and adult learning and training so that they can be school leaders in providing training to their colleagues in this area. However, teacher-librarians need to be sensitive to the priorities and skills of their mirror-images (other teachers) and the school administration. Principals and teachers don't need to be persuaded that students need to be taught how to access and effectively use information that is available in many formats, from the world-wide web to traditional print sources. Neither do they need to be convinced that resource-based learning, with its emphasis on the student being actively involved, is appropriate and preferred in today's schools. In our research on classroom practices, 146 teachers in seven schools across four districts were asked to indicate the extent to which (rare, occasionally, frequently) they employed resourcebased learning in their teaching. In their responses, $79 \%$ responded that they employed it frequently (the range was $54 \%$ in one school to $100 \%$ in another).

For any one to assume the role of "expert" and approach administrators or teachers with the intent of persuading them to adopt such priorities would be ill-advised since the underlying assumptions of ignorance would be quite rightfully resented. Yet, it is true that neither resource-based learning nor the teaching of the necessary information skills are found in all classrooms. The problem is that school staffs have few images of successful implementation. For example, teachers want professional development in how to integrate computer technology, particularly new information technology, into their classroom practices. In Study Four, the provincial study of school improvement, of all initiatives that promoted school improvement, technology was noted as the most significant by all respondents (administrators in schools and district offices, teachers, students, department of education personnel).

We think that teachers and principals need to observe and be engaged in concrete examples of such integration. For example, teachers generally agree that students should have access to the Internet, that skills surrounding such use should be integrated into the curriculum, but they need to see what it looks like in practice. That is why the image of Ruth (one of the teacher-librarians in Table 2) introducing grade three students in a rural and remote school to a whale expert, located hundreds of miles away at the provincial university, through the use of a computer network, is a powerful example of how technology can be integrated into a science unit:

I'll tell you an interesting thing we did with the Whale Unit, bringing technology into it. You are familiar with Dr. John Lien at the university?...Well, we got him on-line one day on Stem net [school computer network] and we brought all the grade three students to the computer laboratory and everyone posed a question to him...they were there when I typed it in he responded to every student so when it came in I took off a hard copy for everybody; the answers to their questions and he sent everybody a new resource information booklet on the whale they had asked information on...they were tickled to death.

It also illustrates that knowing that there is information on the Web about whales is quite a different matter from developing a unit for grade three students which will integrate such information into meaningful instruction. The online interaction with the whale expert was carefully researched and planned, and there was total curriculum integration and follow-up.

Although, in the schools we studied, we were told that the greatest needs for professional development was integration of new information technology in the curriculum, it was clear that school staffs also need examples of how the teacher-librarian can be directly engaged in other forms of resource-based learning. For example, one principal admitted that he had an incorrect perception of the role of a teacher-librarian, that he saw the role as clerical and managerial, until he was "trained" by the teacher-librarian who joined his staff, that through her actions he realized what the role ought to be:

I walked in and saw the goals and objectives of the unit were all set up and there were two or three teachers working together and the students in about five or six different centres and every day they would just rotate. And I said, "Hey, this is working...you can see learning here." 
If teacher-librarians are to survive, we were told, this is where there is a need to show the value of their contributions. They have to show that their work is directly or indirectly related to students' learning outcomes. They may be working with other teachers in the implementation of large, ambitious resource-based units, but, we were also told, this method of connecting the teaching of the skills and the curriculum creates problems. First, they are too time consuming, and even worse, they can be intimidating for some teachers who are not involved in them. We were told of cases where the school's learning resources center and the time of the teacher-librarian was completely scheduled for implementing such units, and the only contact between the teacher-librarian and the classroom for the school year was limited to this intensive three or four week unit. Our understanding of changing school leadership, the needs of students and teachers, and the role of the teacher-librarian has convinced us of the seriousness of this situation. Even a teacher-librarian like Ruth (Table 2), trained in, committed to, and successful with this model, admitted that she has stopped developing new units and has chosen instead to work directly with classroom teachers to integrate skills directly into the classroom instruction on a day-by-day basis (such as in the whale unit reported above). Instead of working in the larger units, more time is being spent supporting teachers and providing the professional support so that the total integration of skills throughout the school can take place. One teacher-librarian saw the task as "building a fire truck as opposed to putting out the fire," and that the aim was to share expertise with the classroom teachers, so that, in some respects, "every single teacher in the school is becoming a Learning Resources teacher." This teacher-librarian has made staff training and development a priority. His school was a national leader in piloting new information technology throughout the curriculum, and most classroom teachers were using computers in their classrooms. As he explained, his role is to learn the new ways of accessing resources, and then train teachers so that they are comfortable using it in the classroom. The teacherlibrarian is then free to investigate other emerging technologies which can help teachers teach and students learn. At the time of the interview, this particular teacher-librarian was just beginning to investigate the potential of satellite technology in the senior level geography course. Questions he was considering included: Was satellite technology available to the school? What would it cost? What hardware and software would it require? Would it help the teachers in the social studies department better meet the objectives of the geography course? Further along was the work with a group of teachers on the use of JAVA software and the development of a multimedia laboratory.

It is through total curriculum integration that students will learn the skills they need, and it is to that end that teacher-librarians must work. This will mean a greater emphasis on their role as staff developers and trainers.

\section{Personal, Interpersonal and Team Skills}

The "new work of the teacher" requires all teachers to have strong interpersonal and team skills. They are expected to relate well to students, to be collaborative team players, to be flexible and open to new ideas. Principals want teachers with friendly and pleasant personalities, who are approachable and collegial. Current curriculum guidelines stress that teachers be facilitators rather than lecturers, that they be strong communicators and school leaders. This is the mirror-image that all teacher-librarians are expected to have. However, as one principal observed, teacher-librarians are expected to have that, and also the "plus:"

A learning resource teacher has to be a good teacher. Do they have to have something above the regular teacher? Well, if I'm a regular classroom teacher and I'm responsible for 150 students that come in my classroom during the year, all I have to do is deliver a good program to them so that they get their money's worth. If you are a learning resource teacher, you have to be able to do that but you also have to be able to work with twentyfive other professionals. I could be a super teacher but I don't have to talk to everyone on the staff, but a learning resource teacher may need better interpersonal skills because not are you only going to work with other kids in the library, you have to work with the teachers as well. 
As difficult as it may be for some to accept, principals, when looking for a teacher-librarian, place much more emphasis on personal, interpersonal, and team skills than they do on specialized knowledge or technical skills. One principal commented:

We all have knowledge of the library, we've all used books all our lives and in our training, so that's the narrow based part. It is the leadership and drive you have that makes the library program work or not. I've had people know about the resources but if they can't make people and the children want to go there, then they're useless to me.

Teacher-librarians themselves saw this area as critical for success. One observed that he worked with other teachers $100 \%$ of his time. Another commented:

I have to be approachable, I have to be flexible enough to drop whatever I am doing and listen to somebody, I have to be a good listener. You have to be a super communicator...and test the waters before you change things...Y You also have to be well organized with your time because it gets busy.

One teacher-librarian related that the need for interpersonal skills is even greater when it involves training teachers to use new information technology:

If you don't have these skills, your job will become very uncomfortable. I think you have to be able to work with people, get along with people. We're talking about an area now which is very strange. We are talking of training teachers to do things which they never had to do and for the most part they are scared to death of it, and you just have to make them feel so comfortable in doing these new things...Skills in getting along with people is what will help you to train these people. The team effort is what will keep you from going insane.

Teacher-librarians need to understand people (whether teachers or students) and know how to treat them differently depending on their personality:

You can't approach every one of them the same way...Some of them, you have to joke along with them, others, it's sort of different. You have got to feel it out and know their personality and get a sense of what's the best way to approach them so they are going to be most comfortable with what they are doing.

Personal attributes of the teacher-librarian also set them apart from their mirror-images. In the interview with one teacher-librarian, it was observed that teacher-librarians need to be risk-takers. It was observed that to live life on the edge of new and emerging technologies means that there is a need to take chances, that occasionally you will fall, "If you fall, you have to jump up and go for it," but that you don't give up. Classroom teachers may have a choice in the level of involvement they have in leading edge information technology. The teacher-librarian does not. The position itself requires a commitment to lifelong learning, to constantly upgrading one's skills, to keeping current. Teacher-librarians, therefore, as mirror-images plus, must exhibit a high tolerance for change and innovation.

\section{Values and Beliefs}

Teacher-librarians, first and foremost, are teachers. This was apparent in an examination of the values and beliefs they held. As teachers, the most deeply held values are connected to the work of helping children learn. We found that there is no distinction between teachers and teacherlibrarians in their primary motivation in teaching - the love of children, illustrated by this comment made by Ruth (Table 2), a primary teacher-librarian who responded to the love and trust of small children, and the joy of helping them learn:

We were doing an activity today and a little boy, it was the first day he wrote down a sentence by himself. Well that made my day! He was so excited and pleased with his work. It's just this kind of every day thing that I value. 
This caring for students exists, but in different manner, in high schools as well, as revealed in this comment from a high school teacher-librarian, Jim (Table 2):

I believe in people, and helping people. I believe in showing them the way and holding their hand until they get so far and then letting them go. There is an extreme satisfaction already in this position from watching somebody light up when they see the information they are looking for.

Teacher-librarians like Ruth and Jim have a moral commitment to improving children's learning opportunities and they tend to be passionate in their belief in equality of educational opportunity for all. In this, teacher-librarians are mirror-images of teachers.

Principals recognize and appreciate this unique contribution of values and beliefs, and it is reflected in their view of what makes a good teacher-librarian-a combination of being a good teacher (the mirror-image of all good teachers on staff) and someone who provides the extra (the mirror-image plus). It is what one principal referred to as "the spark in the eye." One principal combines love for children and knowledge of technology as the primary characteristics of teacherlibrarians:

I think the most important thing for a teacher-librarian is to like kids. That is the first step. The next thing is to have the latest technical skills to turn a kid on. Teaching isn't what it was like 20 years ago...they should be committed to their job, committed to kids, they must be willing to go the extra mile.

More and more teachers are able to meet this expectation as they become comfortable in using modern technology. Teacher-librarians need to reflect this mirror-image and also bring values and beliefs which, although they may be shared by others on staff, are essential to their role- the belief in and commitment to the process of helping all students learn how to learn; the need for all students to learn the skills which will enable them to become independent, lifelong learners; and commitment to the concept of intellectual and physical access to information for all, not just some, students.

To value the love of lifelong learning for oneself and others, and to hold a passionate belief in providing equal opportunity for all in this quest, is the "mirror-image" of values and beliefs held by teachers and teacher-librarians. However, creating a collaborative learning environment, commitment to independent lifelong learning, and commitment to building "the fire truck as opposed to putting out fires," that is the real "plus" of the teacher-librarian.

\section{The Importance of the Mirror-image in Gaining the Principal's Support}

In all the four studies that we used in our analysis for this work, we have found school principals to be extremely influential as educational leaders. They were identified by all stakeholders as the primary source of leadership for the school. In Study One with eight schools and 139 teachers, $72 \%$ of the teachers rated the principal as 4 or 5 on a Likert scale of 1-5 ranging from "little" to "a lot." In Study Four with 19 districts, 155 principals, 279 teachers, 223 parents, and 69 students, the most consistently high rating (on the same Likert scale described above) for leadership contribution to school improvement was afforded to school principals by all groups: district office, mean=4.00; school administrators, mean $=3.95$; teachers, mean $=4.00$; and parents, mean $=4.16$. Interview data from all studies clearly indicate that most of the leadership is school based and that, indeed, the principal is the primary source. Even in one school that was struggling with school improvement and where the principal's abilities were questioned by the staff, most recognized that leadership for school improvement came from the principal. One teacher commented, "The principal is attempting to lead the process and is attempting to empower people and to identify strengths and weaknesses, but I don't know how serious [sic] this is being taken."

These studies reveal that principals have a major role to play in the success of the learning resources program. The principals we studied are committed to resource-based learning, are student focused, and eager to engage in initiatives which provide students with lifelong independent learning skills. All eight principals interviewed in Study Three see the integration of computer technology in the curriculum as a priority, and all have made considerable gains in obtaining access to the Internet. 
The schools range from one of the most advanced in the use of computer technology to ones where it is just beginning, but it is a priority by all, not all have access to the Internet.

Principals have a major influence over the decision to hire and retain a teacher-librarian on staff. One principal was allocated a half-time teacher-librarian by the school board, but had made it full-time by reducing the music teacher to half-time and using the other half for the teacherlibrarian's position. She justified her position this way: "there is absolutely no comparison in the value. The school can't function without the teacher-librarian in my estimation"; and she described her work as the "very key" to the improvements in teaching in the school. Principals also have a key role to play in the selection of the type of individual hired in the school. One principal mentioned actively lobbying to obtain the type of teachers (including teacher-librarian) needed and how this was not an easy task: "I'm putting a lot of effort into trying to orchestrate getting people I want here...you have no idea how hard it is...it would take some lobbying." The characteristics principals look for in both teachers and teacher-librarians are similar: They want strong teachers who will make a difference in students' learning in the school. Type of degree or certificate (for example, a Master's degree or a diploma), even technological ability (which was seen by all as important), are much less significant than the qualities of a good teacher.

Our research shows that the principal's support can enhance or destroy the teacher-librarian's relationship with the staff, and thus success in the job. As part of Study Three, principals and teacherlibrarians sketched an illustration of their perception of leadership in their own schools. These diagrams (Figures 1 - 4) are very revealing. For example, Figure 1 reveals that Principal One saw school leadership in a traditional, hierarchical model. In her interview, she made it very clear that she saw high school teachers as specialists and as quite different in training and orientation from primary or elementary teachers:

I've always found that high school staffs were different. Their courses are their speciality, they are the experts. Joan is doing global issues which is resource based learning but she is doing all the footwork herself. She has the background, the research, and the education, so she does it herself.

She then commented, "the library teacher we used to have would go to the teachers and offer assistance." It is significant she used the term "library teacher," for it was clear that she expected the elementary trained teacher-librarian to help them use the library and little else, and that high school staffs had to be treated differently from elementary school staffs:

Our last two librarians were trained in primary, and they expected to see a carry-over from one school to the other but it doesn't happen. It's not that the staff is being malicious, it's just their way of doing things. To force them to do a planned unit won't work for the teachers. It may make the librarian happy. So I told her it's her job to make the teachers happy. If they are happy with the information they are getting, I appreciate it. If she offers help-I may not ask for it-but I appreciate it when she does it. Or if she offers to put up a display, or put something on the bulletin board, I appreciate the helpful but non-obtrusive assistance. I think the teachers feel this way as well.

It is not surprising that Principal One's leadership chart (Figure 1) reveals that the teacherlibrarian is off to one side, insignificant, not connected to teachers or any one else except the principal (the "boss"). Her box was the smallest one drawn, and it was added only after Principal One was asked where the teacher-librarian fitted in the diagram. Teacher-librarian One is in Principal One's school, and her drawing (Figure 2) corroborates the interpretation of the principal's view, and illustrates how she perceives her 


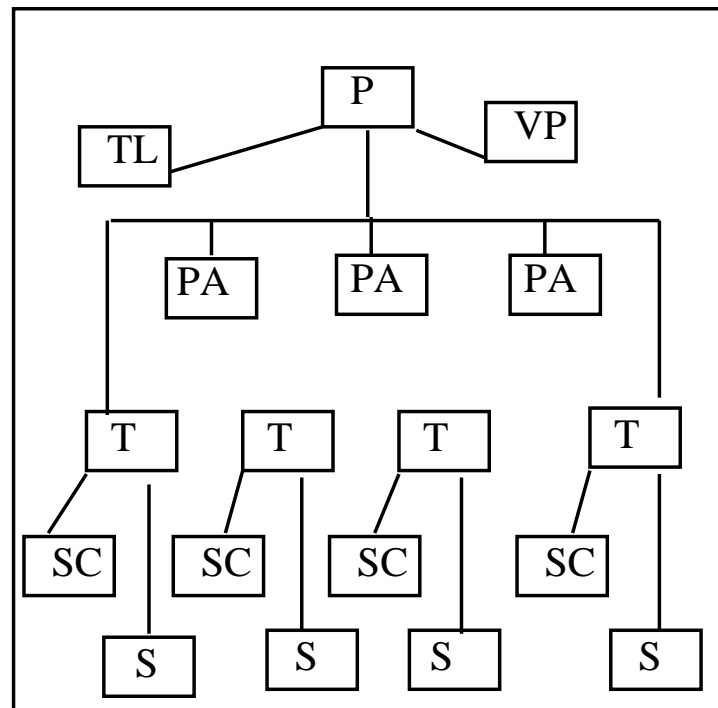

Figure 1: Leadership sketch by Principal One*

* Codes for Fig.1-4 are as follows:
$\mathrm{P}=$ Principal $\quad \mathrm{SC}=$ Student Council
$\mathrm{TL}=$ Teacher Librarian $\quad \mathrm{PA}=$ Parents
$\mathrm{VP}=$ Vice-Principal $\quad \mathrm{S}=$ Students
$\mathrm{T}=$ Teacher $\quad \mathrm{PL}=$ Public Lib. $\mathrm{Bd}$

Figure 2: Leadership Sketch by TeacherLibrarian One

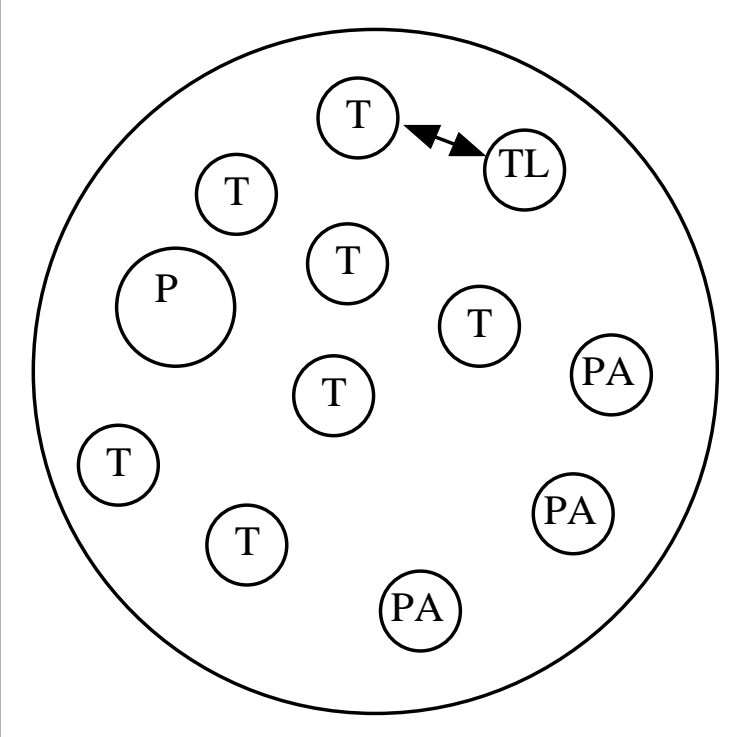

Figure 3: Leadership Sketch by Principal Two

Figure 4: Leadership Sketch by Teacher-Librarian Two 
role as one of insignificance in a crushing bureaucracy. She is not even in the hierarchy; instead, she is a tiny dot outside it. Trapped in such a situation, Teacher-librarian One is well aware that she does not have the respect and support of her principal. When asked what is required in order to be an effective teacher-librarian, it is hardly surprising that her first comment was: "knowing that the principal backs you is one of the important things."

This situation described above exists in none of the other seven schools in Study Three. In all other instances, the teacher-librarians, regardless of their qualifications are seen by the principals as school leaders. [All teacher-librarians were trained, either having an undergraduate diploma (after degree) or an M. Ed. in School Resource Services.] Within the interviews from Study Three, there were comparisons made to the similarity of the role of vice-principal and teacher-librarian; in fact, Teacher-librarian Two (Figure 4) is also the vice-principal. Several principals indicated, on their leadership charts, that the role is very similar to that of the vice-principal in that it is a key leadership role in the school; and several teacher-librarians compared their position to the vice-principalship, explaining that they work with all staff and are the ones that staff members come to for resources and assistance. In those schools where comparisons were not made to the role of the vice-principal, the teacher-librarian's role was compared to that of a department head. In the schools in which there is a definite effort being made to develop strong collaborative cultures, the teacher-librarian is seen as a strong teacher-leader, one of a number on the staff. The diagram drawn by Principal Two (Figure 3 ) illustrates a school in which the principal, vice-principal, and teacher-leaders (including the teacherlibrarian) work together.

The diagrams and comments of Principal One (Figure 1) and Principal Two (Figure 3) provide an interesting contrast. Principal One believes that teachers have interests quite different from hers:

One of the things I find is that at some schools the teachers share the workload of building the school profile, but I find with my staff, they like to focus on their teaching subjects and don't like to have that interfered with. So, they want me to do it, which is fine because if I make them do it they tend to get rebellious...They want to teach. They want to be left alone to teach...they want to focus on their subjects and they don't want to be sitting around until six or seven in the evening, talking theory or writing mission statements.

She believes that the school is a hierarchical structure with her as "the boss:"

I view it [leadership in the school] as a hierarchy, which isn't necessarily as I would like to see it, but I still see me as the center of movement, forcing the staff to take action. They learned last year that I wasn't going to back off. If things had to be done, I was going to do it. I still see myself as being a pusher even when the staff doesn't want to be pushed. If I have a strong vision of something I believe in, I might go ahead with it even if the staff doesn't agree with it. Simply because I believe sometimes they don't make decisions that might be best for the community, but might be best for themselves...My vision is to get Stemnet [computer Internet access] in this school, and whatever I have to do to get it, I will do it.

Being at all times the formal leader, she cannot change roles and become at other times a committee member, a team player. She observed of committees:

I told the technology committee I didn't even want to be on it, but the committee didn't move it for a year, so I gave it another push. So even though I've attempted to set up these committees, they haven't worked in the sense that they haven't taken ownership of it.

Principal Two, on the other hand, recognizes that at times he must assume a formal leadership role, but in his role as instructional leader, he sees himself as a leader among leaders. The diagram of leadership he drew (Figure 3) reveals that he is comfortable being a team player. The hierarchy is not 
totally gone, as he revealed in his interview and as he explained his diagram. In his interview he comments:

I'm plant manager, to a certain extent; and I think I am seen as the person with the final authority. Any problems that they bring to me, we discuss them, and finally I have to make the final decision on what is to happen. The collaboration takes place but I think they do expect me to have some vision, to spark some thoughts-where from here, that sort of thing. We all bring suggestions, and then we explore them-is this a good idea or is it not a good idea? It's not me bringing my vision and imposing it, it's brought in the form of a suggestion and we look at the advantages and disadvantages and collaboratively we make a decision on it. The teacher-librarian fits in as one of the other regular teachers in that group. It's got to be a collaborative process for teachers and teacher-librarian to develop resource-based learning.

This view helps explain why the teacher-librarian in Principal One's school felt so defeated (Figure 2) and why the teacher-librarian in Principal Two's school, who is also the school's vice-principal, (Figure 4) feels so empowered. There is marked difference in the acceptance and support in the two schools. The problem is that teacher-librarians may find themselves in either type of situation. Although new models of educational leadership are emerging, in our research we can see the difficulty some principals have in moving towards the collaborative model. It is also clear that, although the new work of the teacher (and teacher-librarian) has been identified, administrators and teachers have different ideas on how this work can be best accomplished. It is not difficult to find principals like Principal One who view the school as a formal hierarchy, with the principal being the "boss" and teachers being subject area experts with minimal interest or involvement in school-wide matters outside their classrooms. However, it is becoming more common to find principals like Principal Two who has reduced the hierarchical structure to the minimum and is striving to build a sense of community. It is easier for teacher-librarians to work collaboratively in this kind of school but, although it is more difficult, it is not impossible for them to work successfully in a school with a hierarchical structure. In all four of our studies, we have observed teacher-librarians (and other teacher leaders) who are successful in schools where administration still clings to formal leadership roles and lines of authority.

Our evidence leads us to believe that teacher leaders (including teacher-librarians) within a hierarchical system first of all need to understand how the principal operates and must work at developing a relationship with him or her. The support discussed earlier, which is so critical to the success of the teacher-librarian's work, won't come automatically. Teacher-librarian One (Figure 2) became a victim, as her diagram of leadership illustrates. Yet, our interview with Principal One reveals that she values expertise. In describing the characteristics she would look for in a teacher-librarian, she said:

I would look for a person who accepted the fact that the staff viewed themselves as their own experts, and would be able to infiltrate that, and have techniques to reach the teacher, to sit down with them and be persistent in reaching the staff, to show them the value of his or her assistance.

In fact, the main problem that Teacher-librarian One encountered was lack of credibility as a high school teacher (the mirror-image of the other high school teachers). This was based mainly on the fact that her initial teacher training was in elementary education (so she was not expected to be a good secondary teacher) and she also made it clear to everyone, including the principal, that her experience and preference was in elementary school teaching. To command the respect and the support of Principal One she needs to do two things: first, show that she is capable of teaching high school students; and second, that she has the competencies that the principal wants.

The importance of credibility as a teacher was reinforced in observations and data from other schools as well. Another teacher-librarian, who is a full-time teacher-librarian shared between an elementary and a junior high school is trained as a secondary teacher with most of his experience in the junior high grades. He is an acknowledged leader in his school district (described as "one of the best" by an assistant superintendent) and running successful programs in both schools. Yet, even he 
reflected on the problem of establishing credibility in the elementary school. He attributed his success at the junior high school partially to his training and background experience:

I came into this as a junior high school teacher where I knew the curriculum well and I could make connections where even people in the subject areas never saw them. I could make suggestions based on this knowledge, and the teacher would probably agree with me.

He has progressed in this school to the stage where teachers initiate activities with him and there is joint planning and teaching. However, in the elementary schools, it has been a greater struggle to obtain the same degree of acceptance with teachers:

There is more reticence. I don't know if it was because I was a junior high school teacher, and they knew it. I certainly had to take some time to get to know the curriculum, to figure out how elementary school worked and how people worked together.

He concluded that the elementary school and the junior high school are "two distinctly different cultures," and that as a teacher-librarian he needed to become part of both.

Teachers (including teacher-librarians) and principals can and do move from the levels where they were initially trained and become teachers or administrators at other levels. However, they all have to prove themselves as teachers within the particular school setting in which they are working before they can hope to establish credibility and contribute in a mirror-images plus role. Successful movement across different levels of the school system requires what the teacher-librarian above did: taking time to understand the school, its curriculum, and its special needs. Only then can teacherlibrarians have the credibility that will allow them to assume a leadership role and influence what is happening in schools. Their relationship with the principal must be built on an understanding of the importance of credibility. Only if the teacher-librarian is perceived to be credible by colleagues in the school will he or she receive the support of the school principal. Without that credibility and support, as one principal commented, "The teacher-librarian is dead in the water!"

\section{CONCLUSION}

Teacher-librarians in a learning organization must function both as members of teams engaged in organizational learning and as leaders of leaders. Images of how to do this are lacking since schools are currently involved in a major paradigm shift in perceptions of school leadership and teachers' work. The images that we have developed from our research are based on teacher-librarians as mirror-images of other teachers and, as well, contributing to the school as a learning organization by being mirror-images plus. In examining the characteristics of the work of teachers and teacherlibrarians, we used four major categories: knowledge base; technical skills; personal, interpersonal, and team skills; and values and beliefs. The knowledge base and technical skills provide new mental models for all teachers. The acceptance of resource-based learning, with its emphasis on life long learning is consistent with personal mastery, a key discipline of the learning organization. New information technology also challenges the mental models of all teachers. Our research clearly indicates that teacher-librarians should lead this endeavor. If they are to assume this leadership role, however, they will have to remain on the cutting edge and must be exemplars of personal mastery. In addition, they will need strong personal, interpersonal, and team skills, if they are to engage in and lead the team learning required in a learning school. They will succeed in meeting this challenge only if they are motivated by deeply held values and beliefs regarding the development of a shared vision, one that includes the right of all to develop a love of lifelong learning and the skills to make that possible. This right extends not only to students but also to their teachers for teacher-librarians must increasingly assume a leadership role in staff development and training.

Our findings suggest that if teacher-librarians are to successfully fulfill this role, they must have the credibility that comes from being the mirror-image of other teachers. Only then will they be able to contribute in their "plus" role of the mirror-images plus. Teacher-librarians also need the mirror-image of other teachers in order to gain the respect and support of the school's most influential leader, the principal. Teacher-librarians who recognize their role as a mirror-images of 
other teachers and as mirror-images plus, and who recognize the need to work with the principal and others toward meeting the needs of students, are beginning to think systemically. We contend that those teacher-librarians who are able to function in this manner are poised to be "pioneering voyagers, reshaping library information centers by engaging future technologies with critical expertise and imaginative joy."

\section{REFERENCES}

American Association of School Librarians. (1996a). Position statement on information literacy: A position paper on information problem solving [On-line]. Available: http://www.ala. org/aasl/positions/PS_infolit.html.

American Association of School Librarians. (June, 1996b). External draft AASL/AECT national guidelines philosophy: Draft \#8 [On-line]. Available: http://www.ala.org/aasl/externaldraft.html.

American Association of School Librarians. (1996c). Position statement on the value of library media programs in education [On-line]. Available:http://www.ala.org/aasl/positions/ PS_value.html.

American Association of School Librarians. (1996d). Role of the school library media specialist in site-based management [On-line]. Available: http://www.ala.org/aasl/positions/ PS_sitemgmt.html.

Association for Teacher-Librarianship in Canada. (1996). Competencies for teacher-librarians: Preliminary draft [On-line]. Available: http:uvic.ca/csla/comp3.html.

Berman, P. \& McLaughlin, M. (1976). Implementation of educational innovation. Educational Forum, 40(3), 345370.

Blase, J. (1993). The micropolitics of effective school-based leadership: Teachers' perspectives. Educational Administration Quarterly, 29(2), 142-163.

Blase, J. (1987). Dimensions of effective school leadership: The teacher perspective. American Educational Research Journal, 24(4), 589-610.

Caldwell, B., Smilanich, R., and Spinks, J. (1988). The self-managing school. The Canadian Administrator, 27(8).

Clark, D. \& Clark, S. (1996). Building collaborative environments for successful middle level school restructuring. NASSP Bulletin, 80(578), 1-16.

Cousins, B. (1996, June). Understanding organizational learning for educational learning for educational leadership and school reform. Paper presented at the annual conference of the Canadian Society for the Study of Education, Calgary, Canada.

Cranston, N. (1994). Translating the 'new organization' into educational settings. Studies in Educational Administration, 60(Summer), 2431.

Deal, T. (1990). Reframing reform. Educational Leadership, 47(8), 612.

Evans, R. (1993). The human face of reform. Educational Leadership, 51(1), 1923.

Fullan, M. (1995). The school as a learning organization: Distant dreams. Theory into Practice, 34(4), 230-235.

Fullan, M. (1993). Change forces: Probing the depths of educational reform. New York: The Falmer Press.

Galbraith, J. \& Lawler, E. (1993). Organizing for the future. San Francisco: Jossey Bass.

Griffiths, D. (1988). Administrative theory. In N. J. Boyan (Eds.), Handbook of research on educational administration (pp. 2751). New York: Longman.

Handy, C. (1995). Introduction: Beginner's Mind. In S. Chawla and J. Renesch, (Eds.), Learning organizations: Developing cultures for tomorrow's Workplace (pp. 45-56). Portland, OR: Productivity Press.

International Association of School Librarianship. (1995). IASL policy statement on school libraries [On-line]. Available: http://www.rhi.hi/ anne/policysl.html.

Laroque, L. \& Coleman, P. (1991). Negotiating the master contract: Transformational leadership and school district quality. In K. Leithwood \& D. Musella (Eds.), Understanding school system administration studies of the chief education officer. New York: The Falmer Press. 
Leithwood, K., Dart, B., Jantzi, D., \& Steinbach, R. (1993). Building commitment for change and fostering organizational learning (Final report). Victoria, BC: Brititish Columbia Ministry of Education.

Louis, K. (1994). Beyond managed change: Rethinking how schools improve. School Effectiveness and School Improvement, 5(1), 2-24.

Louis, K., Kruse, S., \& Raywid, A. (1996). Putting teachers at the center of reform: Learning schools and professional communities. NASSP Bulletin(580), 10-21.

March, C. (1988). Spotlight on school improvement. Sydney: Allyn \& Unwin.

Marsick, V. \& Watkins, K. (1996). Adult educators and the learning organization. Adult Learning, 7(4), 18-20.

Murphy, J. \& Hallinger, P. (Eds). (1993). Restructuring schooling: Learning from ongoing efforts. Newbury Park, CA: Corwin Press.

Newfoundland Department of Education (1991). Learning to learn: Policy and guidelines for the implementation of resource-based learning. St. John's, NF: Queen's Printer.

Pellicer, L., Anderson, L., Keefe, J., Kelley, E., \& McCleary, L. (1990). High school leaders and their schools. volume II: Profiles of effectiveness. National Association of Secondary School Principals, Reston, VA. (ERIC Document Reproduction Service No. ED 319 139)

Redding, J., \& Catalanello, F. (1992). The fourth iteration: The learning organization as a model of strategic change. Thresholds in Education, (18), 47-53.

Ryan, S. (1995). Introduction: Beginner's Mind. In S. Chawla and J. Renesch, (Eds.), Learning organizations: Developing cultures for tomorrow's workplace (pp. 279-292). Portland, OR: Productivity Press.

Sarason, S. (1990). The predictable failure of educational reform. San Francisco: Jossey-Bass.

Senge, P. (1990). The fifth discipline. New York: Doubleday

Senge, P., Roberts, C., Ross, R., Smith, B., \& Kleiner, A. (1994). The fifth discipline fieldbook. Toronto: Doubleday.

Sergiovanni, T. (1995). The principalship: A reflective practice perspective. Boston: Allyn \& Bacon.

Sheppard, B. \& Brown, J. (1996). One school district's experience in building a learning organization._The Morning Watch, 24(1-2), 1-12.

Sheppard, B. \& Brown, J. (1995). A shift to schoolbased management in Newfoundland and Labrador, Canada. International Directions in Education, 4(1), 4.

Sparks, D. (1996). A new form of Staff Development is essential to high school reform. The Educational Forum, 60(3), 260-266.

Stoll, L \& Fink, D. (1996). Changing our schools. Philadelphia: Open University Press.

Toronto Board of Education. (1996). The role of the teacher-librarian in the Toronto board of education [On-line]. Available: http://www.target.tbe.edu/lib/model/lib-inf/lib-inf2.html

Vail, K. (April, 1996). Data-driven decisions. The Executive Educator, 18(4) 28-30.

Weber, J. (1989). Leading the instructional program. In School leadership: Handbook for excellence. Office of Educational Research and Improvement. (ERIC Document Reproduction Service No. Ed 309 513)

Woods, P. (1986). Inside schools: Ethnography in educational research. London: Routledge \& Kagan Paul. 